the biochemistry section. Immunity mechanisms are also being studied at a molecular level in the biophysics section.

One major difficulty in work on foot-and-mouth disease virus has been the lack of a suitable line of cells which can be continuously cultivated, and which is still sensitive to infection by the virus. The report describes how this difficulty has been overcome by the use of a diploid line of hamster fibroblasts. Cells of this line are highly sensitive, and are now used extensively for all types of research on the virus. The hamster cells are also proving to be suitable for mass culture and therefore for large-scale vaccine production.
It is gratifying to see from the report that the problem of disease security is continuing to attract the attention it deserves, and much of the building programme for the period under review has been concerned with improved isolation units and air-filtration equipment.

This will be the last report by Dr. I. A. Galloway, who has now retired after twenty-four years as director and who is succeeded by Dr. J. B. Brooksby. The wide scope and large scale of the activities described in the report are a particularly suitable record of the development which has taken place in the Institute under Dr. Galloway. M. G. P. STOKER

\title{
THE SHIRLEY INSTITUTE
}

T HE idea of co-operative industrial research is well established in Britain, for there are no fewer than fifty research associations, each financed jointly by the industry concerned and the Department of Scientific and Industrial Research. In few instances has the work been more successful than in the case of the Cotton, Silk and Man-made Fibres Research Association, as is made abun. dantly clear in the 1964 annual report of the director, Dr. D. W. Hill *, and by the stimulating exhibits which could be seen recently when the laboratories were open to members.

The Research Association, colloquially known as the "Shirley Institute", has established for itself a world-wide reputation based on its work on the constitution, reactivity and processing of cotton, but its activities now include work for the silk and the man-made fibres industries, particularly after the merger with the Rayon Research Association a few years ago. It is not possible in a short note even to summarize the wide range of topics at present being studied in the Association's laboratories, but two or three perhaps deserve special mention, because they illustrate the vision and foresight which have characterized the planning of the research programme and the close collaboration which exists between the Association's scientists and member firms.

One of these is the design of the automated system for producing yarn from raw cotton. The project has been developed to such an extent that mill trials are now in progress. As Dr. Hill states, "the introduction of automated processing is the one way in which this country

* Report of the Council and Statement of Accounts for the year ended Members of the cotton, Silk and Man-made Fibres Research Association, held on Thursday, November 5,1964 . can compete with Eastern countries that have a large surplus of cheap labour". The system could be adapted to work in most modern mills, although considerable capital expense would be involved.

The Institute has for some time been carrying out research on the behaviour of fibres during stretching, and it was found that when fibres such as polyethylene are stretched they tend to split longitudinally. A similar phenomenon occurs when films are stretched, and from this observation has emerged a completely new method of producing fibres simply by stretching films under suit. able conditions. Yarns can be spun from these fibres and the technique opens up many important possibilities.

Almost all the basic operations involved in converting fibres into finished cloth are being investigated in an attempt to obtain maximum efficiency in conventional techniques and to develop new ones, but an important aspect of the choice of topics is that the probable cost of each project has been assessed in the light of possible financial return. It is interesting that considerable stress is being laid on the production of stretch fabrics.

The work of the Institute is characterized by the careful balance between 'pure' and 'applied' research so that projects range from fundamental investigations to the solving of members' problems. During the past fifteen months covered by Dr. Hill's report, some 3,000 technical enquiries were dealt with. The scientific quality of the work at the Shirley Institute is high, and the present report shows that the Association is pursuing imaginative and profitable lines of research which will ensure that it continues to be one of the most highly regarded centres of fibre research. C. S. WHEwELL

\section{SCIENCE OF THE FABRICATION OF CERAMICS}

\begin{abstract}
THE meaning of the term 'ceramies' is to-day in a state of flux. Materials scientists tend to apply the term to any inorganic non-metallic material. Most of the workers in the field of ceramics-both the traditional and the new-feel that ceramics is a technological subject and that it is the fabrication process which brings the old and the new ceramics together. Basically the process may be described as the shaping of an article from a powder and its consolidation into a monolithic article by a high-temperature 'sintering' treatment. The scope of the meeting of the Basic Science Section of the British Ceramic Society, held at Brighton during October 12-14, 1964, was thus logically divided into three main sections: (1) preparation, characterization and properties of powders (chairman, Prof. J. White, University of Sheffield); (2) forming processes (chairman, Mr. A. Dinsdale, British Ceramic Research Association); (3) sintering and related processes (chairman, Dr. P. Murray, U.K. Atomic Energy Authority, Harwell). Some new and interesting processes
\end{abstract}

which did not fit into this scheme were dealt with in a fourth section entitled "Other Fabrication Routes" (chairman, Dr. J. Williams, U.K. Atomic Energy Authority, Harwell).

In order to acquaint the participants with recent developments and present-day thinking, the first three sections were each preceded by an introductory lecture. The first of these was given by J. Williams, who leads the vory large ceramic team of the Metallurgy Division at Harwell. He emphasized the importance of the surface, since the driving force in the sintering process is the surface-free energy, and considered both its physics and its chemistry. Particle size and shape, and the deformation characteristics of powders, determined by their defect structure, were some of the points discussed.

The usual methods of characterization of a powder are by its particle size (for example, determined by optical and/or electron microscopy), its crystal size by X-ray line broadening, and surface area by the Brunauer- 